\title{
Seroprevalence of Border Disease in Danish Sheep and Goat Herds
}

\author{
By C. Tegtmeier ${ }^{1,2}$, H. Stryhn ${ }^{1}$, A. Uttenthal ${ }^{1,3}$, A.M. Kjeldsen ${ }^{4}$ and T. Krogh Nielsen ${ }^{1}$
}

${ }^{1}$ Danish Veterinary Laboratory, Copenhagen, ${ }^{2}$ DAKO A/S, Glostrup, ${ }^{3}$ Danish Veterinary Institute for Virus Research, Lindholm, ${ }^{4}$ The Danish Agricultural Advisory Center, Skejby, Denmark.

\begin{abstract}
Tegtmeier C, Stryhn H, Uttenthal Å, Kjeldsen AM, Nielsen TK: Seroprevalence of Border Disease in Danish sheep and goat herds. Acta vet. Scand. 2000, 41, 339-344. - A study was conducted in 1994-96 with the aim of assessing the serological prevalence of Border Disease (BD) among sheep and goats in Denmark and to investigate possible relations to herd factors. From each of 1000 herds, 2 blood samples were obtained from animals older than 1 year. The examination for antibodies was performed using a blocking ELISA detecting antibodies to pestivirus. Data from 815 herds were analysed statistically by the maximum likelihood method in a multinomial model. The estimated herd prevalence was 0.083 and the estimated individual prevalence within the positive herds was 0.50 . There was no difference between the prevalence in sheep and goat herds. Records for well over half of the herds could be combined with data from the Danish Central Husbandry Register. No association between occurrence of BD and herd size was found. Cattle were registered as contemporarily present on 135 out of 521 herds which was shown to be strongly associated to BD. The estimated herd prevalences of BD among farms with and without contemporary cattle were 0.24 and 0.042 , respectively.
\end{abstract}

pestivirus; serology; border disease virus; bovine virus diarrhoea; herd prevalence; individual prevalence; register data; maximum likelihood.

\section{Introduction}

Border Disease (BD) virus belongs to the genus Pestivirus, allocated in the family Flaviviridae (Murphy et al. 1995). The virus is closely related to Bovine Viral Diarrhoea virus (BVDV), and pestivirus exchange between sheep and cattle occurs. Both viruses have been shown to be capable of inducing infection across species (Løken 1995b, Nettleton et al. 1998). Naturally occurring BD in sheep is considered to have a world-wide distribution, and the antibody prevalence proportions vary in the range 5\%-50\% between countries. (For simplicity, the shorter term prevalence is used throughout for prevalence proportion). Postnatal infections are usually sub-clinical, whereas transplacental intrauterine infections result in embryonic deaths, abortion, congenital disorders or immunotolerance, i.e. persistent infection with BDV. Such persistently infected lambs can show tremor, abnormal body conformation and hairy fleeces ("hairy-shaker"), and the outcome is often fatal. The disease is rare in goats and characterised by abortion (Løken 1995a, Nettleton et al. 1998).

Studies on the seroprevalence within the sheep population in our neighbour-countries have been performed in Norway in 1984-86 (Løken et al. 1991), Sweden in 1986-87 (Lundén et al. 1992) and Germany in 1986-87 (Frost et al. 1991). These surveys have shown between 3\% and $30 \%$ of the animals to be seropositive, often with a considerable variation in the preva- 


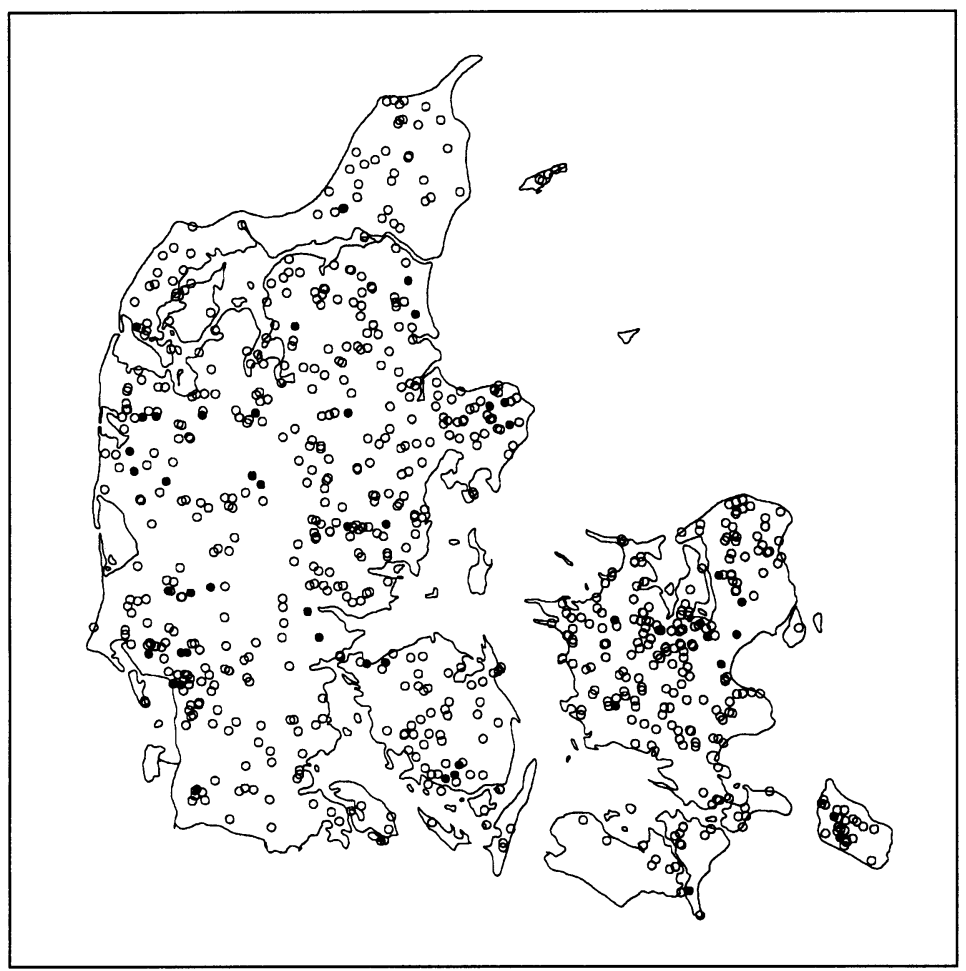

Figure 1. Map of Denmark showing the location of 772 herds and their serological response for Border disease: $\bigcirc$ : seronegative herd, O: seropositive herd (at least one sample positive).

lence between different regions. Also, serological evidence of BD in goats has been described from a number of countries (Løken 1995b).

The aim of the present study was to assess the serological prevalence of BD among sheep and goat herds in Denmark, and to investigate the possible relationship between seroprevalence of $\mathrm{BD}$ and contemporary presence of cattle on the same farm.

\section{Materials and methods \\ Blood samples}

Blood samples were obtained as a subset of samples from a voluntary surveillance programme on Maedi-Visna, Caprine arthritis and encephalitis virus. The samples originated from healthy animals without clinical signs of pestivirus infection. All samples included in the present study were collected between November 1994 and March 1996. During that period, approximately 3000 of the 5000 sheep and goat herds in Denmark participated in the surveillance programme. Samples from all regions in Denmark were included in the study (Fig. 1). From each of 1000 herds, 2 blood samples from animals older than 1 year were obtained, i.e. 2000 blood samples in total.

\section{Serology}

Serum was obtained by centrifugation of full blood at 7-900 $\times \mathrm{G}$ for $15 \mathrm{~min}$. The serum was then tested in a blocking ELISA as previously described by Bitsch \& Rønsholt (1995). In brief, Nunc Maxisorp plates (Glostrup, Denmark) were precoated with swine anti-BVDV IgG followed by a blocking step using $5 \%$ nor- 
mal swine serum. After washing, 50 microliter of the sheep/goat serum was applied to each well, immediately followed by application of 50 microliter of inactivated BVDV Ag. The BVDV antigen used consisted of a mixture of 2 Danish field strains (UG59, BVD258) reacting well with the circulating reacting BDV/BVDVstrains (Rønsholt, personal communication). The plates were incubated overnight at $5^{\circ} \mathrm{C}$, and then washed and incubated with rabbit antiBVDV serum for 1 hour at $37^{\circ} \mathrm{C}$. Swine antirabbit Horse-radish Peroxidase (DAKO, Glostrup, Denmark) was used as the secondary antibody. Washing between incubation steps was performed using PBS, $0.5 \% \mathrm{NaCl}, 0.1 \%$ Tween 20. Ortho-phenylene-diamine (KemEnTec) was used as substrate. Sera were considered antibody-positive when blocking of the OD value to more than $50 \%$ of the average value of a negative control was obtained.

As BVDV and BDV are very closely related it is not possible to distinguish between BDV and BVDV antibodies in the diagnostic tests available. Thus the ELISA-detection assay used in the present study detects ovine, bovine and caprine pestivirus antibodies without any further discrimination. For simplicity, a seropositive reaction in sheep or goat is referred to as a positive BDV reaction, whereas a seropositive reaction in cattle is referred to as a reaction to BVDV.

\section{Register data}

Information on each farm such as animal type (sheep, goat, cattle), herd size, geographic location and presence of cattle at the same herd were extracted from the Danish Central Husbandry Register (CHR-register). All results were handled anonymously.

When combining the BDV samples with register data, missing or non-compatible data were encountered in a number of cases. As an example of non-compatible data, the register might indicate a sheep or goat herd not to be active at the time of testing. In general, we took in such cases the conservative approach of excluding the herd from the part of the study involving register data, so as to avoid any bias from erroneous observations. Technical details on the handling of register data are available upon request from the corresponding author.

\section{Statistical analysis}

The number of herds with 0,1 or 2 seropositive reactions (denoted by $n_{o}, n_{1}$ and $n_{2}$ ) follow a multinomial distribution with corresponding probabilities $\mathrm{p}_{0}, \quad \mathrm{p}_{1}$ and $\mathrm{p}_{2}$ (such that $\left.\mathrm{p}_{0}+\mathrm{p}_{1}+\mathrm{p}_{2}=1\right)$. We denote by $\mathrm{q}$ the herd prevalence (probability of at least one positive animal in the herd) and by $p$ the within-herd individual prevalence (probability of an animal to be positive within a seropositive herd). Assuming the individual prevalence to be constant across animals older than 1 year in positive herds, as well as perfect sensitivity and specificity of the test, the probabilities $\mathrm{p}_{0}, \mathrm{p}_{1}$ and $\mathrm{p}_{2}$ are related to the herd and individual prevalences $p$ and $\mathrm{q}$ as follows,

$\mathrm{p}_{0}$ (prob. of 0 positive samples) $=1-\mathrm{q}+\mathrm{q}(1-\mathrm{p})^{2}$

$\mathrm{p}_{1}$ (prob. of 1 positive sample) $=2 \mathrm{qp}(1-\mathrm{p})$

$\mathrm{p}_{2}$ (prob. of 2 positive samples) $=\mathrm{qp}^{2}$

The parameters of the model were estimated by the maximum likelihood method. In particular, the estimates for $p$ and $q$ are given by the equations

$\mathrm{q}=\left(\mathrm{n}_{1}+2 \mathrm{n}_{2}\right)^{2} / 4 \mathrm{n}_{2}\left(\mathrm{n}_{\mathrm{o}}+\mathrm{n}_{1}+\mathrm{n}_{2}\right)$, $\mathrm{p}=2 \mathrm{n}_{2} /\left(\mathrm{n}_{1}+2 \mathrm{n}_{2}\right)$,

unless the values thereby obtained fall outside their permitted range $(0<\mathrm{p}, \mathrm{q} \leq 1)$, which would happen only in extreme cases.

Confidence intervals were constructed by the profile likelihood method (Venzon \& Moolgavkar 1988). Statistical hypotheses were tested by likelihood ratio statistics, using chisquare reference distributions (Cox \& Hinkley 1974). 


\section{Results}

Serology

Due to insufficient herd registration, and occasional submission of several samples from the same herd, only 815 herds were included in the statistical analysis, corresponding to 1630 samples. There was no statistically significant difference in the proportion of positive samples among the excluded and retained data.

Approximately $15 \%$ of the samples originated from goats. The proportion of positive sheep and goat samples were almost identical (and far from statistically different).

In 764 of the 815 herds, both serum samples were negative for BDV-antibodies, whereas one and 2 samples tested positive in 34 and 17 herds, respectively. Thus, the observed individual prevalence was $68 / 1630=0.0417$, and for the herd and within-herd prevalences the following estimates were obtained (with $95 \%$ confidence intervals):

q (herd prevalence):

$\mathrm{p}$ (individual prevalence

in positive herds):

No marked regional differences were observed, and seropositive herds were found in all parts of Denmark (Fig. 1).

\section{Register data}

The data showed no statistically significant relationship between herd size (grouped into size categories) and occurrence of BD, (based on 636 herds, after exclusion of missing or noncompatible data).

In the analysis of a possible relationship between BD and contemporary presence of cattle within the same farm, only 521 herds were included. In 135 cases, cattle were registered as contemporarily present in the herd, whereas in 386 cases no information indicated the presence of cattle within the herd. The data showed a clear, statistically significant $(p<0.001)$ difference between herds with and without cattle.
The corresponding estimated herd and individual prevalences in the 2 groups of herds were (with $95 \%$ confidence intervals),

Herds with cattle:

$$
\text { q: } 0.22(0.14,0.39)
$$

Herds without cattle:

$$
\text { q: } 0.055(0.023,0.25) \quad \text { p: } 0.31(0.06,0.63)
$$

The indicated difference in the individual seroprevalences between the 2 groups of herds was clearly non-significant. Therefore, the individual prevalence and the two herd prevalences were re-estimated under the assumption of the same individual BDV prevalence in herds with and without cattle:

Herds with cattle:

$$
\text { q: } 0.24(0.15,0.42) \quad \text { p: } 0.43(0.25,0.61)
$$

Herds without cattle:

$$
\text { q: } 0.042(0.021,0.082) \quad \text { p: } 0.43(0.25,0.61)
$$

\section{Discussion}

From the present survey, $8.3 \%$ (confidence interval: 6-12\%) of the Danish sheep and goat herds were estimated to be BDV-seropositive; i.e., antibodies to BVDV or BVD were detected without further discrimination, as detailed in materials and methods. Furthermore, within a seropositive herd about half of the animals (35$64 \%$ ) were estimated to be seropositive.

In the planning and analysis of prevalence studies it is important to distinguish between herd and individual prevalence (Christensen \& Gardner 2000), and to decide whether the aim of the study is to estimate one of them or both. The present study was focused on herd prevalence and included a large number of herds, with only 2 samples per herd. In such cases, the risk of missing a positive herd by random selection of seronegative animals may be appreciable (depending on the level of individual prevalences). This has been taken into account by the statistical model and estimation method. 
To illustrate the importance hereof, the crude rate of herds with at least one positive animal was $51 / 815=0.063<0.083$, and clearly underestimates the herd prevalence. The analysis was based on an assumption of the same individual prevalence in positive herds. With only 2 animals tested per herd, this assumption cannot be tested from the data, and varying individual prevalences cannot be accounted for. Therefore, if the assumption is considered critical, it would be desirable to test more animals per herd. Note that the observed individual prevalence is in general a biased estimate of the overall individual (population) prevalence.

The prevalences found in the present study differ from those in previous Scandinavian studies, both in their values and by their method of calculation. A Swedish study of BD among 704 animals in 54 sheep herds indicated a herd prevalence of about $10 \%$; however, in no herds the individual prevalence exceeded $13 \%$, and the observed individual prevalence was only 1.1\%. (Lundén et al. 1992). In a Norwegian survey of pestivirus infection among 3712 ewes from 103 sheep flocks, the herd prevalence was about $20 \%$ and the observed individual prevalence was $4.5 \%$ (Løken et al. 1991). In both of these studies the individual prevalence was markedly lower than in the present study, even when taking our wide confidence bounds into account. This may possibly be explained by sampling from different population subsets. First, in the Swedish study $59 \%$ of the tested animals were lambs, whereas the Norwegian study and out study included only ewes and animals older than 1 year, respectively. A positive correlation between age and prevalence of pestivirus antibodies is expected, where the increase in prevalence with age probably reflects the accumulation of long-lasting antibodies or the cumulated increased risk of exposure due to age. Second, the herds in our study constituted $16 \%$ of all herds but were part of a voluntary surveillance programme, and may therefore not be representative of the entire population.

No marked regional differences were found, which is contrary to the Norwegian survey, where a considerable regional difference was observed, i.e. the prevalence was high in the western part of Norway and zero in northern Norway (Løken et al. 1991). Differences in the Danish and Norwegian agricultural structure and geography can explain this discrepancy because the farms are located much more uniformly in Denmark than in Norway.

There was a clear association between contemporary presence of cattle on the farm and the seroprevalence of BDV. This is in accordance with the Swedish study where the proportion of BDV-positive flocks was found to be higher among flocks with contact to cattle than among cattle-free flocks (Lundén et al. 1992). Unfortunately, the register data used in the present study, did not allow to examine the BVD-status of the cattle from the herds included. Therefore, a comparison of the BD-status of the small ruminants as determined by the seroprevalence, and the BVD-status of the cattle within the same herd was not feasible. However, the association between seroprevalence to BD and contemporary cattle on the farm is an important observation in itself.

An eradication programme for BVD in cattle has been running in Denmark since 1994, first on a voluntary basis but compulsory since April 1996. However, no policy regarding BD in the small ruminant species has so far been formulated. Awareness of BD is however of great importance, as the small ruminants may serve as a reservoir and thus contribute to maintain the infection within the cattle population. Conversely, sheep and goat herds may be infected from introduction of persistently infected calves or BVD-positive cattle. Future studies should elucidate the importance of small ruminants as a reservoir for maintenance of BVD- 
infection among cattle (and vice versa), in view of the great efforts put into eradication of BVD in Denmark these years.

\section{References}

Bitsch V, Rønsholt L: Control of bovine viral diarrhoea virus infection without vaccines. Vet. Clin. North. Am. Food. Anim. Prac. 1995, 11, $627-$ 640.

Christensen J, Gardner I: Herd-level interpretation of test results for epidemiological studies of animal diseases. Prev. Vet. Med. 2000, 45, 83-106.

Cox DR, Hinkley DV: Theoretical Statistics. London, Chapman and Hall, 1974.

Frost JW, Westphäling I, Krauss H: Detection of the prevalence of antibodies against Border disease in sheep in south and central Hessen (Germany). Tierarztl. Umschau 1991, 46, 533-535.

Lundén A, Carlsson U, Näslund K: Toxoplasmosis and Border disease in 54 Swedish sheep flocks. Seroprevalence and incidence during one gestation period. Acta. Vet. Scand. 1992, 33, 175-184.

Løken T: Border disease in sheep. Vet. Clin. North. Am. Food. Anim. Prac. 1995a, 11, 579-596.

Løken T: Ruminant pestivirus infections in animals other than cattle and sheep. Vet. Clin. North. Am. Food. Anim. Prac. 1995b, 11, 597-614.

Løken T, Krogsrud J, Larsen IL: Pestivirus infections in Norway. Serological investigations in cattle, sheep and pigs. Acta. Vet. Scand. 1991, 32, 2734.

Murphy FA, Fauquet CM, Bishop DHL, Ghabrial SA, Jarvis AW, Martelli GP, Mayo MA, Summers MD (eds.): Virus Taxonomy: The Sixth Report of the International Committee on Taxonomy of Viruses. Springer Verlag, Wien, 1995.
Nettleton PF, Gilray JA, Russo P, Dlissi E: Border disease of sheep and goats. Vet. Rec. 1998, 29 , 327-340.

Venzon DJ\& Moolgavkar SH: A method for computing profile-likelihood-based confidence intervals. Appl. Statist. 1988, 37, 87-94.

\section{Sammendrag}

Seroprovalens of Border Disease $i$ danske fåre- og gedebesatninger.

En undersøgelse udførtes i 1994-96 med det formål at bestemme den serologiske prævalens af Border disease (BD) blandt fåre- og gedebesætninger i Danmark, samt at belyse mulige sammenhænge med forskellige besætningsfaktorer. Fra 1000 besætninger blev der udtaget to blodprøver af dyr, som var ældre end 1 år. Undersøgelse for antistoffer blev foretaget ved blokerings-ELISA. Data blev analyseret statistisk ved hjælp af maksimum likelihood metoden i en multinomialfordeling. Den estimerede besætningsprævalens var 0.083 , og den individuelle prævalens proportion i positive besætninger blev estimeret til 0.50 . Der kunne ikke påvises nogen forskel på fåreog gedebesætninger.

For godt halvdelen af besætningerne kunne data kombineres med et udtræk fra CHR-registeret. Der kunne ikke vises nogen sammenhæng mellem forekomst af BD og besætningsstørrelse. Samtidigt kvæghold i besætningen var registreret på 135 ud af 521 besætninger, og data tydede på en klar sammenhæng mellem kvæghold og forekomst af BD. Den estimerede besætningsprævalens blandt besætninger med og uden kvæghold var henholdsvis 0.24 og 0.042 .

(Received April 10, 2000; accepted July 12, 2000).

Reprints may be obtained from: H. Stryhn, Danish Veterinary Laboratory, Bülowsvej 27, DK-1790 Copenhagen V, Denmark. E-mail: hes@svs.dk, tel: +45 353001 00, fax: +4535300120. 